\title{
Does Greater Accountability Improve the Quality of Delivery of Public Services? Evidence from Uganda
}

\author{
Klaus Deininger* \\ Paul Mpuga*"
}

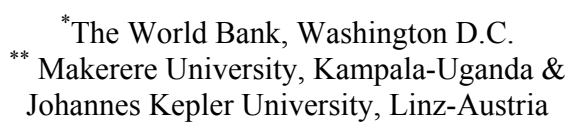

World Bank Policy Research Working Paper 3277, April 2004

The Policy Research Working Paper Series disseminates the findings of work in progress to encourage the exchange of ideas about development issues. An objective of the series is to get the findings out quickly, even if the presentations are less than fully polished. The papers carry the names of the authors and should be cited accordingly. The findings, interpretations, and conclusions expressed in this paper are entirely those of the authors. They do not necessarily represent the view of the World Bank, its Executive Directors, or the countries they represent. Policy Research Working Papers are available online at http://econ.worldbank.org. 


\title{
Does Greater Accountability Improve the Quality of Delivery of Public Services? Evidence from Uganda
}

\begin{abstract}
While the importance of corruption as a possible impediment to foreign investment in an international context is now well realized, it is not clear to what extent corruption affects, either directly through bribe-taking or indirectly through inadequate quality of public services, the level of economic activity by domestic entrepreneurs. Using a large survey from Uganda, we show that domestic and foreign entrepreneurs, government officials, and households are unanimous in highlighting the pervasiveness and importance of corruption. Efforts to establish institutions to deal with corrupt practices have not been matched by public education on the proper procedures. The fact that such lack of knowledge on procedures to report corruption increases households' risk of being subject to bribery and significantly reduces the quality of public service delivery leads us to conclude that improved accountability will be important to reduce the incidence of corruption and improve delivery of public services.
\end{abstract}

\section{Introduction}

Higher levels of economic integration across countries and greater availability of information provide significant potential for efficiency gains, but have also helped to expose corruption. Corruption is defined as the abuse of public power for private benefit, and is a key constraint to efficient allocation of economically valuable resources, effective provision of public goods and services, and people's confidence in the state and the legal system. High levels of accountability, defined as a system of open and transparent controls, can help to improve economic efficiency and reduce the scope for discretionary action by public officials. Regulations are critical for the development process in at least two ways.

First, it is widely held that a significant part of the growth that is expected to reduce poverty in developing countries has to come from private investment. Rent seeking by partial and corrupt officials, however, increases the costs associated with entrepreneurial investment and may lead foreign investors to take their business elsewhere. Corruption also forces domestic entrepreneurs to go underground, leading to high levels of informality and a narrow tax base. Complaints about lack of transparency, high levels of regulatory intervention and corruption, and the cost that these impose on doing business are at the core of recent empirical evidence gathered from entrepreneurs in the Global Investment Climate Survey.

A second reason is that developing countries require significant investment in public goods, such as infrastructure, education, and health, to attract private investment and create a broad-based and egalitarian economic development. However, high levels of corruption have been shown to bias public spending in undesirable directions and reduce the quality of provision of such services. Unless non-corrupt and transparent mechanisms to allocate public funds are available and officials are accountable for the allocation, their full economic potential may not be realized. The harmful and potentially far-reaching importance of corruption, as well as the fact that high levels of economic growth do not necessarily lead to a reduction of corrupt practices, is now widely recognized. As a consequence, the issue has moved up on the agenda of international institutions and institutional reforms to combat corruption, including anticorruption commissions, in many countries. 
This paper uses the case of Uganda to explore three issues in more detail. First, we are interested in the prevalence and incidence of corruption across different government departments as assessed by the private and the public sector, and the extent of knowledge on how to respond to corruption and hold officials accountable. Second, we are interested in factors that affect the extent to which households are exposed to bribery, hypothesizing in particular that greater ability to hold officials accountable will decrease the likelihood of such bribery. Finally, we expect that such accountability will affect not only corruption but also the quality with which public services will be provided.

The paper is structured as follows: Section two links the topic to the broader literature and discusses the conceptual framework as well as the strategy to implement econometric tests using the data at hand. Section three describes the data from Uganda's second integrity survey and uses them to provide descriptive evidence on the incidence of corruption across institutions, households' exposure to corrupt practices and their knowledge of procedures to report corruption, and the quality of public service delivery. Section four provides econometric evidence to identify the impact of greater accountability on the incidence of bribe taking and the quality of public service delivery. Section five concludes by summarizing the evidence and translating it into a number of recommendations for policy.

\section{Conceptual model and relation to the literature}

Issues of governance have long been one of the neglected areas in development economics (Bardhan 2000). Recently, however, there has been increasing interest in quantifying the levels of corruption, transparency, and accountability across countries to improve understanding of their impact and identify measures that can help to reduce undesirable consequences. This has brought to the fore the fact that corruption is widespread and constitutes an important obstacle to economic growth, in particular through its impact on the nature and quality of spending on public service provision and the investment decisions by foreign and domestic private entrepreneurs that, in return, will affect the size of a country's tax base. As developing countries share many characteristics that make them particularly prone to high levels of corruption, a consensus that actions to improve governance would be warranted and needed in addition to growth-enhancing policies is now emerging among international financial institutions. While this has resulted in the establishment of institutions that can help combat corruption, less attention has been devoted to the need to also enhance accountability in order to make these institutions work. To illustrate this point and provide a basis for subsequent empirical investigation, we develop a very simple model of the way in which greater accountability affects the incidence of corruption and the quality of public service delivery and discuss how this can be implemented econometrically using data from Uganda's second integrity survey.

\subsection{Insights from the literature}


Thanks in part to more widespread availability of information, higher levels of economic integration and the associated greater emphasis on competitiveness and efficiency, and the reduction of ideological barriers, interest in corruption and governance has been surging in recent years (Bardhan 1997, Tanzi 1998), coinciding with greater awareness of the importance of institutions in the process of development (Nugent and Robinson 2002, Acemoglu 2003). As private investment is likely to be a key determinant of growth in most developing countries (Bengoa and Sanchez-Robles 2003), a conjunction of institutional features that have been commonly lumped together under the heading "investment climate" becomes of critical importance In fact, based in most instances on assessments by outside investors or local experts, cross-country indicators to assess various aspects of this phenomenon, compare them, and measure their impact have been developed by academics (Feld and Voigt 2003), independent institutions such Transparency International (Eigen 2002) and the World Bank (Djankov 2002, Batra et al. 2003).

Descriptive evidence based on these efforts highlights that a combination of high taxes, arbitrary regulations, policy uncertainty, and low quality of public service delivery and ill-developed financial markets are universally perceived as key constraints to business development. These phenomena are not independent of each other but can in many cases be traced to high levels of corruption that significantly reduce the scope for economic growth and development. This is confirmed by a large number of crosscountry econometric studies that have used indices of different aspects of the phenomenon to demonstrate the harmful impact of corruption on aggregate growth through a variety of mechanisms (Mauro 1995, Bardhan 1997, Tanzi 2000, Mo 2001, Rivera-Batiz 2002, Feld and Voigt 2003). Although more limited, evidence from within country studies supports these results (Gomez and Gallon 2002, Fisman and Gatti 2002b). Two main channels through which such an effect comes about are the type of public services provided and the efficiency of their provision and the level of investment by private entrepreneurs.

A first channel through which corruption affects economic growth is by affecting the composition of public spending and the quality of public service provision. It has long been known that large investment projects provide greater opportunities for government bureaucrats to obtain kick-backs than spending on education and health projects or on operation and maintenance. Indeed, empirical evidence demonstrates that countries with high levels of corruption spend too little on education and health (and on operation and maintenance of past investment) (Mauro 1998), thereby resulting in a significant reduction in the productivity of public investment in countries where, partly due to high cost of raising public revenue, domestic resource mobilization is already insufficient (Ades and Di Tella 1997). This will make it harder for government to fulfill its most important role, to provide public goods (including the enforcement of contracts and protection of property rights), and to impose regulatory controls as a response to market failures. In addition to reducing economic growth, the quality of public service delivery, and foreign investment, this can, in the extreme, lead to a significant reduction in the legitimacy of the state (Tanzi 
1998). The lack of publicly provided infrastructure capital, in turn, has been shown to constitute an important bottleneck for the development of private firms (Reinikka and Svensson 2002) which, through creation of unnecessary barriers to entry, reduces competition and innovation by small start-up firms (May et al. 2002, Broadman and Recanatini 2002). In fact, this could well be one of the reasons that infrastructure investment improves economic growth only if associated with the right governance environment (Esfahani and Ramirez 2003).

In addition to this indirect effect via the level of public provision, corruption also has a more direct impact on the level of economic activity because the need to pay a random bribe in order to get things done (or even to protect a business from looting) distorts incentives and acts as an arbitrary and unpredictable tax that adds significantly to the cost of doing business in a country. There is strong evidence that levels of foreign direct investment are much higher in countries where individual freedom and respect for civil and property rights is high (Harms and Ursprung 2002). The corruption-induced increase in the transaction cost for private business has often prompted foreign investment to either enter into specific types of joint ventures or to move to other countries (Smarzynska and Wei 2001). Domestic firms are likely to move abroad to escape the net of regulations which many countries require to register a business (Djankov 2002), or in order to escape the demands of a corrupt bureaucracy and a weak legal system, they often join the informal economy, thereby further reducing the potential for generation of government revenue, provision of public goods, and economic development (Friedman et al. 2000).

The issue of corruption is particularly relevant in the context of economic development because developing countries share many of the characteristics that make them particularly prone to corruption (Tanzi 1998). These include a plethora of regulatory interventions, regimes of taxation that are comparatively high but contain many loopholes, non-transparent procedures, high levels of discretionary government spending, limited scope for own revenue generation by local governments (Fisman and Gatti 2002a) and bureaucrats' ability to award large rents (e.g. from natural resources and public lands or licenses) in a discretionary manner. These tendencies are exacerbated by low quality of the bureaucracy and public sector wages (Van Rijckeghem and Weder 2001), limited ability to impose administrative controls, and non-transparent rules, laws, and processes. High barriers to new business entry and soft budget constraints on incumbents are particularly important institutional factors that provide an opportunity for corruption. In fact, disproportionate dependence on aid transfers has been shown to reduce accountability and thus the quality of governance (Knack 2001). As long as the political economy of aid was dominated by the demands of the cold war environment, few donors seem to have paid attention to this issue (Alesina and Weder 2002), but this seems to be gradually changing with international financial institutions as well as bilaterals increasingly aware of the importance of good governance as a precondition to make aid achieve its desired objectives (Burnside and Dollar 2000). To address this, 
donors have in many countries (including Uganda) supported the establishment of institutions to deal specifically with issues of corruption. However, little is known about the extent to which such institutions have been effective or the extent to which increased levels of accountability would help improve their effectiveness, as would be suggested by a number of recent studies that have pointed to an important role of the mass media to put policy making on a more informed basis (Stromberg 2001, Besley and Burgess 2002) and demands to bring in new actors such as NGOs and to foster transparency and open debate as a means to expose corrupt practices (Merhotra 2002, Goetz and Jenkins 2002, Ebrahim 2003).

Uganda provides an interesting case to study this issue. Despite high levels of economic growth since the early 1990s, the country has ranked continuously in the bottom part of Transparency International's corruption perception index. ${ }^{1}$ Low levels of transparency and accountability have been identified as potential obstacles to continued progress in reducing poverty (Francis and James 2003). The goal of reducing corruption features prominently in the country's development strategy and an Inspector General of Government (IGG) and a Ministry of Ethics and Integrity have been set up to help put this into practice. In addition, the Leadership Code Act of 2002 provides for minimum standards of behavior and conduct by leaders serving in public offices (including government departments and statutory bodies) and for an enforcement mechanism through the IGG's office. It requires leaders to declare there incomes, assets and liabilities at the time of assumption of office and thereafter every two years (Republic of Uganda, 2002a). Thus the country provides a good example to derive lessons on the incidence of corruption, the potential importance of good governance for service delivery, and the effectiveness of mechanisms to improve governance and accountability.

\subsection{Conceptual model}

Assume that a public administrator receives exogenously given transfers (e.g. from central government) of size $M_{p}$ to provide public goods and at the same time has to approve private investments of size $M_{q}$. The monetary benefit to the administrator from investing $x$ in public goods or from an investment of $x$ by the private sector is given by the functions $b_{p}(x)$ for public and $b_{q}(x)$ for private investment, respectively. We assume that these functions are well-behaved (i.e. $b^{\prime}(x)>0, b^{\prime \prime}(x)<0$ and $b(x)<x$ for any $x$ ). ${ }^{2}$ In each case, the administrator has the possibility of diverting a share $l_{i}<1(i=p, q)$ of the money involved to own use. This money can be kept if the looting is not detected but an amount $d_{i}\left(l_{i} x\right)$ with $d^{\prime}(x)>0, d^{\prime \prime}(x)>0$ and $d(x)>x$ has to be repaid if diversion of $x$ is detected. The probability of being detected is $p(a, I)$ which has as its functions the level of accountability $a$ and the institutional framework $I$ and which is concave in both its arguments. The problem of the administrator is then to choose $l_{\mathrm{i}}(i=p, q)$ to maximize

\footnotetext{
${ }^{1}$ While the expansion in the number of countries in the corruption perception index compiled by Transparency International makes a consistent assessment more difficult, Uganda ranked as $43^{\text {rd }}$ out of 51 countries in 1996 (the first year when the country was included), $74^{\text {th }}$ of 85 in 1998 , $80^{\text {th }}$ out of 90 in 2000 , and $113^{\text {th }}$ out of 133 in 2003.

${ }^{2}$ The latter just implies that the monetary benefit will not be greater than the amount invested.
} 
Solving this problem will yield equilibrium levels of "theft" or corruption $l_{i}^{*}\left(M_{i}, a, I\right) ; i=p, q$. It is intuitive and easy to show that, for any given $M_{i}$, the derivatives of $l_{i}^{*}$ with respect to its second and third element are non-positive. In other words, since for any interior solution, the administrator will embezzle funds up to the point where the expected loss from being caught equals the marginal benefit from the investment, any improvement in accountability or institutional quality will reduce the level of embezzlement and thereby automatically increase the amount of money that is spent in productive public or private investment. The implication from the model, and the central hypothesis to be tested empirically below is that, within any given institutional setup, higher levels of accountability will be associated with public servants being less likely to demand bribes from the private sector and, in the public sector, have greater incentives to not only demand less fees for their services but also deliver them more effectively.

\subsection{Empirical implementation and estimation strategy}

As our data contain information on bribe taking as well as a subjective assessment of changes in the quality of public service delivery, the key issue to be confronted before being able to proceed to estimation is to find an empirical correspondence for accountability and institutional quality ( $a$ and $I$ in equation 1). As to the institutional framework, we assume that the only source of variation in institutional quality is across sectors, implying that we can use sectoral dummies to absorb differences in this variable. As a measure of accountability, we use the share of households who indicate to know where and how to report cases of corruption, something that can be justified in a situation where, as in the case of Uganda, an explicit anti-corruption policy exists and institutions to enforce this policy have been established, but very few households actually know how to make use of these institutions.

One econometric issue that arises in this context is that those who are more likely to be subject to corrupt practices or who have been hurt by corruption in the past and those for whom such knowledge is more easy to acquire will be more likely to make the investment needed to find out how to report corruption. This implies that knowledge of ways to report corruption is not exogenous and that, in order to obtain an unbiased estimate, instrumentation will be needed. The level of education will make it easier to acquire information on how to report corruption but is extremely unlikely to directly affect the probability of being affected by corruption and can therefore be used as an identifying instrument (Greene 1995). If the knowledge on corruption were measured as a continuous dependent variable, standard two-stage least squares could be used to deal with this problem. In cases with a limited dependent variable, using the predicted value from a first-stage probit regression does produce unbiased results (Angrist 1991). We therefore first estimate a probit equation for households' knowledge on how to report corruption

$$
K_{i}=\alpha_{1}+\alpha_{2} \boldsymbol{X}_{i}+\mu_{i}
$$


where $K_{i}$ is an indicator for whether or not the household reported to know the procedures for reporting corruption, $\boldsymbol{X}_{i}$ is a vector of household characteristics, and $\mu_{i}$ is an iid error term. In particular, $\boldsymbol{X}_{i}$ includes the head's educational qualification, the household's level of consumption expenditure and wealth (as proxied by dummies for ownership of the house, a bicycle, or a motorized vehicle) as well as the mean expenditure in the village, the sector of main economic activity, a dummy for rural areas and regional dummies. We expect that higher levels of education and asset ownership and employment in formal sectors of the economy will all increase a households' likelihood of knowing the necessary procedures and use the predicted value as one of the right hand side variables in subsequent regressions that aim to test the impact of accountability (as proxied by this variable) on the incidence of bribe-taking and the quality of public service delivery.

Determinants of bribery: As the survey at hand provides a direct measure of whether or not a household who, during the last 6 months had approached a specific institution, was required to pay a bribe as well as the amount that needed to be paid, we can estimate an equation of the form

$$
B_{i}=\alpha_{1}+\alpha_{2} \hat{K_{i}}+\alpha_{3} Z_{i}+\mu_{i}
$$

where $B_{i}$ is an indicator of whether or not a bribe had to be paid, $K_{i}^{\wedge}$ is the predicted value from regression (2) as discussed above, $\boldsymbol{Z}_{i}$ is equal to the vector $\boldsymbol{X}_{i}$ as defined above with the exception that educational attainment is not included, and $\mu_{i}$ is again an iid error term. Based on the conceptual discussion, we expect $\alpha_{2}$, the coefficient on our measure of accountability, to be negative and highly significant. To assess whether there are externalities from knowledge at the village level we also include the level of predicted knowledge at the village level.

Quality of public services: There are two reasons to complement the above regression on determinants of bribe-taking with information on the quality of public services. One is that the former regressions could suffer from selectivity bias to the extent that certain households may not even approach government institutions because they expect not to be attended or to have to pay bribes. A second one is that, higher levels of accountability might have an independent impact on public servants' motivation to provide services in an effective manner. As the quality of public services will be affected by many factors (e.g. the pre-existing level of infrastructure, staffing levels, etc.) that are not available in our data, we complement the analysis of the level of satisfaction with an assessment of changes in the perceived quality of service delivery. As is well known in the literature, use of changes eliminates time-invariant fixed effects and will thus produce estimates that are less likely to be affected by bias. Defining $Q_{i j k}$ as the (perceived) quality of provision of service $k$ by individual $i$ in village $j$ and $\Delta Q_{i j k}$ as the change in this variable, the equation to be estimated is given by

$$
\Delta Q_{i k} / \Delta Q_{i k}=\alpha_{1}+\alpha_{2} K_{i}^{\wedge}+\alpha_{3} C_{j}+\alpha_{4} S_{j}+\alpha_{5} \boldsymbol{R}_{j}+\mu_{i}
$$


where $K_{i}^{\wedge}$ is the predicted knowledge of reporting procedures as defined earlier, $C_{j}$ and $S_{j}$ are the mean levels of corruption and expenditure, and $\boldsymbol{R}_{j}$ is a vector of regional dummies, all for village $j .{ }^{3}$ The rationale for these variables is straightforward: while we expect households' knowledge on how to report corruption to improve the incentive structure for bureaucrats, higher levels of pre-existing corruption would reduce the level of service quality and dampen the impact of better knowledge. At the same time, higher levels of village wealth are likely to increase the amount of resources available and thus make improvements in service quality more likely. This implies that we expect $\alpha_{2}$ and $\alpha_{4}$ to be positive and $\alpha_{3}$ to be negative.

\section{Data and descriptive evidence}

Uganda's second national integrity survey provides evidence on perceptions regarding corruption by firms and public sector employees which are used to illustrate the importance of the issue. We then discuss descriptive statistics from household level data on the extent of bribery, the quality of public service delivery, and knowledge of measures to reduce corruption to provide the background for subsequent econometric investigation.

\subsection{The Uganda National Integrity Survey}

Our data come from the Second National Integrity Survey which was conducted for the Inspectorate of Government in the second half of 2002 to improve the empirical basis for policies and programmes to assess the incidence of corruption in different institutions and strengthen accountability and the quality of public service provision (Republic of Uganda 2002b). The survey covered 12,190 households in 55 of Uganda's 56 districts that were in existence at the time the sample was drawn. In addition, an institutional module was administered to 618 private entrepreneurs as well as 480 public sector representatives.

The goal of the household survey was to be representative at the district level. In each district, $20 \%$ of the sub-counties were randomly selected, starting with District Headquarters. Within these, two to three local councils (LC1s, the lowest administrative units) and subsequently households were selected randomly. The public sector survey was administered in eight districts - two in each of the country's four regions: Central, East, West and North. ${ }^{4}$ A list of institutions and their respective representatives was drawn up with the goal of interviewing all units responsible for administration of law and order or provision of public services at the national, district, or sub-district level. While the non-response by Ministers at the national level was substantial, the sample is fairly complete at the district and sub-district level, consisting of about 60 interviews for each of the eight districts. For the private sector survey, the database of firms

\footnotetext{
${ }^{3}$ In each of these cases, respondents were asked to assess the level of improvement on a 1-5 scale. Table 8 provides results for the determinants of "significant" (top ranking) and "moderate" (second ranking) improvements in each of these sectors.

${ }^{4}$ These are Kampala, Lira, Mbale/Tororo, Mbarara, Arua, Jinja(Lugazi/Kakira), Masaka and Kasese.
} 
paying VAT in the same eight districts where the public sector survey was implemented was used as a sample frame, even though this is far from being an ideal solution. ${ }^{5}$ One implication is that the sample, with a total of 623 interviews, is strongly biased towards Kampala where about $60 \%$ of the enterprise interviews were conducted. A second consequence is that, even though efforts were made to adjust the sectoral composition of the sample, the final distribution of interviews by sector is quite different from the contribution of different sectors to the country's GDP. ${ }^{6}$ This implies that, at least in geographical terms, the private and public sample are likely to be quite complementary to each other and leads us to interpret their results jointly in the discussion below.

\subsection{Assessment of corruption by entrepreneurs and public officials}

Compared to households who, if they were not in contact with officials, may not have a good basis for an assessment of corruption issues, those included in the public and private sector surveys are all likely to have had first hand experience of dealing with the public sector and, in the case of private firms, are likely to use this as the basis for economic decisions. We focus on respondents' perceived level of corruption in different government institutions. Table 1 lists, in ascending order, the share of respondents from public and private sectors, respectively, who rated a certain government department as "not honest" or "highly corrupt".

The table illustrates that the incidence of perceived corruption varies widely. A significant number of institutions, led by the Central Bank, the Ministry of Foreign Affairs, the Office of Ethics and Integrity, and the Ministry of Finance, but also including the Parliament, the Ministry of Education, and the President's Office were perceived to have a high level of integrity. The IGG, the Ministry of Health, the Privatization Unit, the Immigration Department and courts are perceived to be more susceptible to corruption. Finally, institutions perceived to be most corrupt are (in descending order) the traffic police, the Uganda Revenue Authority, Tender Boards, the Electoral Commission, the non-traffic part of the police, and the Ministry of Defense. This suggests that, while confidence is high in top levels of the executive, it is limited for the institutions that are meant to implement decisions and the organs for enforcing the law. Comparing columns 1 and 2 of table 1 illustrate that the ranking of institutions' level of corruption is quite consistent between private and public sector respondents; though there are slight differences in ratings these rarely affect the ranking of institutions. ${ }^{8}$

\footnotetext{
${ }^{5}$ As the Uganda Bureau of Statistics (UBOS) was still in the process of completing its Census of Business Establishments, it was not possible to use the a more comprehensive register of businesses instead, despite the obvious shortcomings of the VAT register. The key issue to bear in mind in interpreting the results is that, given that the VAT register contains only about 6000 firms, compared to 160,000 expected to be included in the list of establishments maintained by UBOS, this biases the sample in favor of larger and more formal firms, most of which have more than 5 employees.

${ }^{6}$ In the final sample, $13 \%$ of the establishments are from agriculture, $16 \%$ from manufacturing, $56 \%$ from services, $12 \%$ from construction, and $3 \%$ from other sectors (including mining).

${ }^{7}$ Respondents were asked to rank corruptability of different public institutions on a scale of 1-3 and, for each institution, did have the option of not responding (i.e. do not have an opinion").

${ }^{8}$ Column 4 marks cases where the difference between the private and the public sector's assessment is statistically significant at the $1 \%$ level. The main difference between public and private responses is that public sector employees identify the ministries of finance and works, as well as
} 
To gain an idea of the perceived severity of corruption, respondents were asked to assess the presence of five increasingly severe forms of corruption, namely favoritism, bribery, embezzlement, extortion, and fraud in the typical government department. ${ }^{9}$ Results, separately for the public and private sector, as well as for different types of private entrepreneurs, are presented in table 2. This confirms that, even though more severe forms of corruption are perceived to be less common, the overall level of confidence in public institutions is quite low: more than three quarters of the respondents believe that favoritism, bribery, and embezzlement are fairly common, prevalent, or very prevalent while $56 \%$ do so for fraud and $42 \%$ for extortion. The picture does not change too much if one focuses only on those who rank different phenomena as either prevalent or very prevalent: $61 \%$ believe that favoritism is prevalent, $50 \%$ do so for bribery and embezzlement and $28 \%$ and $18 \%$, respectively, believe that fraud and extortion are prevalent.

While one would expect public employees to assess the quality of public institutions more favorably than respondents from the private sector, differences between the two are less pronounced than one would think, echoing other studies in Africa (Goldsmith 2003): Bribery is more of a concern to foreign and local corporations than the rest. By comparison, foreign (but not local) corporations complain less about embezzlement and extortion. While favoritism seems to be a complaint particularly of local corporations, there are no systematic differences in the ranking of fraud across different parts of the private sector.

\subsection{Households' experience with corruption and public service provision}

Household level data allow us to complement the above ranking with measures of incidence and impact of corruption on the broader population. Table 3 reports descriptive statistics for the sample which, in view of the forced inclusion of district headquarters, is somewhat biased towards urban households. ${ }^{10}$ This can be illustrated by comparing the results to what is obtained in the nationally representative Uganda National Household Survey (UNHS). We find that $15 \%$ of households, as compared to about $25 \%$ nationally, are female headed and that only $59 \%$, as compared to about $80 \%$ in a national sample, are rural. The income gap between rural and urban areas is illustrated by the fact that $73 \%$ of the bottom quintile are from rural areas, compared to $44 \%$ in the top quintile. As to economic sectors, one-third of the sample households ( $49 \%$ in the bottom and $21 \%$ in the top quintile) are headed by individuals whose main source of income is the agricultural sector, $21 \%$ by traders, and about another third by professionals and craftspeople.

parliament and the courts, as more corruptible than respondents from the private sector. The latter, by contrast, have less confidence in the integrity of the President's Office, the IGG and the NSSF, as well as the privatization office, the ministry of defense, the immigration department, the URA, and the traffic police.

${ }^{9}$ Corruption in general is defined as the use of public power for private gain. In this context, favoritism implies that benefits are obtained through personal relations between those with power and those seeking favors (jobs, land, or other property), bribery as the demand for payment for services that should be freely given, embezzlement as the diversion of public property/money for private use, extortion as the demand for money, services or other gains with threats, and fraud as the use of explicitly illegal methods to obtain such private gain. Respondents were asked to assess the presence of the different forms of corruption in government on a 1-5 scale where 1 implies non-existent, 2 very limited, 3 fiarly common, 4 prevalent, 5 very prevalent.

${ }^{10}$ Despite repeated requests, we were unable to obtain weights that would have allowed to generate nationally representative figures. 
Our indicator for incidence of corruption is whether, upon personally contacting a particular institution, a household was forced to pay a bribe for services that should have been delivered for free. The top panel of table 4 provides descriptive evidence for the aggregate and by expenditure quintile. ${ }^{11}$ Not surprisingly, the share of households who have done so varies: Panel 1 illustrates that about two thirds reported to have approached a health institution, about $44 \%$ and $40 \%$ education or local administration, respectively, and about $22 \%$ the police and institutions charged with providing productive services. Poorer households had generally less contact with the institutions of concern. ${ }^{12}$ As this may result in selectivity bias, we complement analysis of these households' actual experience of bribery with the perceived satisfaction with service provision by all households in the sample as discussed in more detail below.

Panels 2 and 3 illustrate that the evidence on corruption is broadly consistent with the ranking of different institutions in the institutional part of the survey: Education emerges as the least corrupt with only $7 \%$ of users having had to pay bribes, followed by local administration $(15 \%)$, health $(21 \%)$, and productive services $(26 \%){ }^{13}$ The police emerge as the country's most corrupt institution - $36 \%$ of the households who had contact with them reported that they had to pay a bribe. The median bribe paid varies from USh 3,000 for administrative services to 15,000 for the police. ${ }^{14}$ In most cases the share of poor users who had to pay bribes was below average and the amount of bribe paid by them less than for the rich, consistent with some wealth-differentiated access and the finding that administrators discriminate among clients to extract maximum revenue (Svensson 2003).

Rankings of departments in terms of users satisfaction with the services provided, as reported in the second part of the table, suggest that users of health, education, and local administration are most content (6.8, 7.6 and 7.2\% "highly" satisfied and 29.1, 38.6, and 24.6\% "somewhat satisfied"). By comparison, only $1.8 \%$ and $3.3 \%$ of the population are "highly" and 9.4 and $12.7 \%$ "somewhat" satisfied with police and productive services, respectively. The variation in assessment of institutional quality over the income distribution is more marked than in the case of bribe-paying. For example, less than $2 \%$ of the bottom two quintiles are highly satisfied, as compared to $6.4 \%$ in the top quintile. Thus, contrary to what one would expect given lower demand for bribes from low-income groups, the poor are consistently less satisfied with the quality of service provision than are the rich, even though the latter pay more bribes. This could imply that many of the poor may not even try to access services because they expect not to be attended or not able to pay the fees needed and that looking at actual bribe payments will thus not be sufficient. ${ }^{15}$

\footnotetext{
${ }^{11}$ Here and below, we distinguish education, health, the police, local administration, and institutions to provide productive services (including those under the ministries of economy, agriculture, water, forestry, and land).

${ }^{12}$ At least in the case of education, this does not mean that they did not use the services under concern.

${ }^{13}$ Survey data indicate that the abolition of user fees in the health sector with effect from March 2001 has been implemented in a relatively effective way, resulting in a significant reduction of the households who reported to have had to pay such fees in the 2002/03 National Household Survey (Deininger and Mpuga, 2004). Unfortunately we do not have data on the incidence of bribe taking before this policy change. The fact that about one fifth of those who used health services reported having to make some (unofficial) payment suggests that, even though governance remains an issue, concerns that the abolition of user fees would cause officials to demand side payments rather than official fees were unfounded.

${ }_{14}^{14} 1$ US\$ is equivalent to about 1,800 USh and that the average daily wage in agriculture is about USh 2,000 .

${ }^{15}$ Future surveys of this type will therefore need to pay more attention to selectivity issues.
} 
Given that there are many factors (e.g. levels of staffing and pre-existing infrastructure) that would affect the quality of service provision but on which we do not have data, econometric analysis might produce biased estimates. Some of these problems can be avoided by looking at changes rather than levels in the quality of service provision. Information on such changes over the last 4 years is available only for education and health. The pen-ultimate panel of table 4 illustrates that about $11 \%$ and $44 \%$ of households thought that teaching had improved or somewhat, respectively, as compared to $17 \%$ and $52 \%$ who believe the same for school buildings, $12 \%$ and $48 \%$ for education facilities (i.e. books and other materials), and 8.5 and $48 \%$, respectively for health services.

The bottom panel of table 4 highlights that, despite a relatively high prevalence of corruption, few of the incidents are actually reported and knowledge about how to do so remains limited. Compared to nearly one third of households who reported to have paid at least one bribe during the last 6 months, only 4.5\% indicate that they ever reported an incident of corruption. More importantly, about $40 \%$ of the sample know of corruption cases that they failed to report. According to the survey, the single most important reason for not doing so is lack of knowledge on the necessary procedures $(40 \%)$, followed by other reasons $(28 \%)$, households being afraid to offend others (19\%), and reporting not being worth the bother (13\%). This suggests that the large majority of corruption cases in Uganda go unreported -and without consequences- not primarily because people fear the social consequences or doubt the effectiveness of doing so but because of a lack of knowledge on procedures. The fact that only $21 \%$ of the overall population ( $13 \%$ in the bottom quintile as compared to $28 \%$ in the top quintile) know how to report corruption highlights that, in the absence of knowledge on the applicable procedures, establishment of national anti-corruption commissions make little difference at the field level.

Before proceeding towards an empirical assessment of the impact of different institutions on the variables of interest, we review responses on the type of institutions perceived to be most helpful in reducing corruption. Table 5 suggests that a more intense public discourse and establishment of institutions with a mandate to deal effectively with misuse of public office need to go together: while the radio, newspapers, church organizations, and local councils, rank among the most important means to help reduce corruption, the president's office, the IGG, and commissions of enquiry are equally important. One clear finding is that the police and the judiciary are not in a good position to establish higher standards of conduct but are rather part of the problem than a solution. On the other hand, regional differences point towards considerable variation across regions; for example in the North where poverty is the highest and the presence of other institutions is low, the IGG, church organizations, and the radio are rated as most important.

\section{Econometric evidence}


Econometric analysis provides considerable support to the hypothesis that lack of knowledge on how to report irregular practices constitutes a constraint to reducing corruption and improving service delivery. Those who know how to report corruption are significantly less likely to have to pay a bribe, to be more satisfied with service delivery, and to perceive greater improvements in education and health over time. In each of the cases, the point estimate of the coefficients is large, suggesting that improving households' ability to take action against arbitrary behavior by bureaucrats is likely to improve the effectiveness of the institutions that have been established to this end and at the same time increase incentives for effective provision of public services.

\subsection{Knowledge of reporting and incidence of corruption}

We first report results from the instrumental equation for knowledge of reporting procedures (table 6, column 1) where the coefficients reported are marginal probabilities. As explained earlier, the predicted value is then used as a right hand side variable to help explain whether households were actually subject to corruption.

Results from the first stage equation illustrate that higher levels of education are associated with significantly better knowledge on how to report corruption; households whose head has upper primary education are 5\% more likely to know the processes involved while those with secondary and tertiary education are, respectively, $10 \%$ and $17 \%$ more likely to know. While higher levels of expenditure at the village or household level are estimated to have a similar effect, they are of a much lower magnitude: according to the estimates, a $10 \%$ increase in village level or household consumption would increase the mean villager's level of knowledge by 0.14 or 0.2 percentage points, respectively. ${ }^{16}$ This is consistent with the hypothesis that, although they are likely to improve knowledge and thus help reduce corruption, higher levels of economic development on their own are unlikely to have a large impact on improving households' knowledge on how to deal with corruption. Professionals are more likely (by 5.5\%) to be aware of mechanisms to report corruption but surprisingly, those with higher levels of assets, proxied by ownership of a permanent house and a bicycle, are not. The fact that female headed households are significantly less likely to know how to report corruption could make them more vulnerable to such practice. Finally, there are marked differences in knowledge across regions; holding constant for other factors, knowledge seems actually to be lower in the country's central region than in others.

Results from probit regressions of the likelihood that households who were in contact with specific institutions during the last 6 months had to pay a bribe are reported in column 2 for the aggregate and column 3-7 of table 6 for individual sectors. Regressions for being affected by corruption overall point towards the importance of knowledge; according to the point estimate knowing how to address corruption

\footnotetext{
${ }^{16}$ Due to space considerations, the results with mean levels of village expenditure are not reported but can be obtained from the authors upon request.
} 
reduces the probability of being subject to bribe-taking by about $25 \%$. Consistent with what one would expect and what emerged from the descriptive statistics, affluent households are significantly more likely to be forced to pay bribes even though wealth also increases the level of knowledge on how to report; ownership of a bicycle increases the probability of being subjected to bribery by almost $3 \%$ and higher levels of consumption imply a further increase. Female headed households, in turn, are estimated to be $11 \%$ less likely to have to pay bribes, more than compensating for their being less well informed. Surprisingly, we also find that once other factors are accounted for, business people and professionals are significantly less likely (by $2 \%$ and $4 \%$ ) to be forced to pay bribes than farmers (the excluded category) and that rural dwellers are significantly more likely to be subject to demands for bribes. This is consistent with evidence that often arbitrarily imposed controls constitute an important impediment for the development of Uganda's agricultural and rural sector (Ellis and Bahiigwa 2003).

This general pattern is supported by regressions for individual sectors: Knowing how to report corruption is estimated to significantly reduce the likelihood of being subject to bribery in all sectors except education. The magnitude of the estimated coefficient is largest (-0.93) for the police followed by productive services (-0.79), administration (-0.35) and health (-0.31), implying that for the police, knowledge of how to report - and presumably the ability to convincingly threaten such reporting to the officer demanding bribes - can almost eliminate bribe-taking. Concerning other variables, the regressions suggest that the police and productive services are more likely to demand bribes from those with higher levels of wealth and less from female-headed households, we also note that bribery by the police and for productive services is significantly higher in the rural than in the urban sector and (at least in the case of the police) lower for these in the business sector. However, the much smaller magnitude of all these coefficients as compared to that for predicted knowledge suggests that greater procedural knowledge is likely to be a key element in any efforts to reduce the incidence of bribe-taking.

\subsection{Satisfaction with and improvements in service delivery}

In view of the sample selection problem discussed earlier, ${ }^{17}$ we complement evidence on bribe payments by those who actually contacted officials in different sectors with factors affecting the level of satisfaction with the quality of services provided in each of these sectors. ${ }^{18}$ We find that, especially in education, the selectivity problem seems indeed to have been an issue -contrary to the earlier regression, the coefficient on predicted knowledge is not only highly significant and positive but also of considerable magnitude, implying that those who know reporting procedures are $23 \%$ more likely to be highly satisfied with services in the education sector (Table 7). While the magnitude of coefficients is smaller for other sectors (from 0.196 in administrative services, 0.171 in productive services, 0.083 in health and 0.048 for the

\footnotetext{
${ }^{17}$ Note that the problem can go both ways: Households may not contact officials because they are satisfied with the services they receive, i.e. there is no reason for doing so, or because they do not expect that doing so will result in any improvement.

${ }^{18}$ Doing so eliminates the selectivity problem but may provide less accurate information.
} 
police), all of them are consistently positive, suggesting that greater knowledge of reporting makes it more likely to receive high quality services, particularly because households' knowledge of how to report corruption or other misbehavior is expected to change the incentive structure for local bureaucrats. The level of corruption in the village is negative for education and health, though insignificant for the remainder, and the level of village expenditure positive and significant for education and marginally significant for health and productive services. The magnitude of the coefficient on predicted knowledge suggests that greater accountability can have a major impact on improving the quality of service delivery.

To ensure that our results do not suffer from bias due to some unobserved information, we complement evidence on levels with information on changes over time for education (separately for teaching, buildings, and other facilities) and health sectors. Results from doing so, illustrated in table 8, support our earlier conclusions in a number of ways. Predicted knowledge about reporting of corruption increases the probabilities of households' reporting improvements in teaching, buildings and education facilities and health by $36,28,29$ and $16 \%$ respectively. ${ }^{19}$ The level of corruption is estimated to have a negative and highly significant impact on teaching, though not on other elements. Village level expenditure is positive and highly significant for education but insignificant for health. This suggests that, while improvements in education were facilitated by availability of more resources, improvements in the health sector were targeted towards poorer rural dwellers. A key reason for this could be the abolition of user fees in the health sector in March 2001 as the reference period for improvements asked for in the survey (i.e. 19982002) includes this but not the initiation of the Universal Primary Education program in 1996. This suggests that empowering people to hold public officials responsible can indeed have a major impact not only on reducing corruption but also on a broader improvement in the quality with which public services are delivered.

This is consistent with contributions to the cross-country literature that have identified effective provision of public services as key determinants of growth in addition to pointing out that accountability may well have an independent role that goes beyond preventing corruption and improving services. However, evidence from within a given country can help to appreciate the potential magnitude of this effect. While our estimates should be treated only as a first approximation that needs to be confirmed by evidence from other sources, they certainly suggest that, at least in the case of Uganda, a move to increase the ability of citizens to hold their (elected and unelected) representatives to account for their actions can be justified on economic grounds as well.

\section{Conclusion and policy implications}

${ }^{19}$ Although improvements in teaching, buildings, and facilities, are highly correlated, the correlation between improvements in health and
education is only about 0.05 . 
While cross-country evidence on incidence of bribery and corruption and their far-reaching economic impact has drawn attention to the importance of governance, micro data at the country level are required to help identify strategies that can assist in confronting this issue in practice. This paper constitutes a first attempt at doing so, thereby illustrating not only that it is possible to design survey instruments that capture key elements of the issue, but also that doing so can yield insights and avenues for policy action.

We find that, even in a country such as Uganda that has traditionally been applauded in the area of its macro-economic policies, issues of governance and corruption remain a serious concern. Households' exposure to bribery is widespread, though differentiated across institutions. Knowledge on ways to confront corruption is limited, and satisfaction with the quality of public service provision is low. Representatives from private and public sectors have an almost unanimous low opinion concerning the integrity of many public institutions -especially those responsible for law enforcement. Respondents point toward independent institutions (including the IGG, churches, and local councils), together with a more open dialogue promoted by radio, newspapers, and television, as important avenues to reduce bribery and corruption.

Even though many households experienced corruption first-hand, lack of knowledge on appropriate procedures is an important constraint to reporting such misbehavior, which is a necessary pre-condition for action by the institutions established for this purpose. Econometric analysis confirms that households' knowledge on reporting corruption is indeed a key factor in reducing their susceptibility to being asked to pay bribes and, in addition, has a positive impact on the level of (as well as changes in) the quality with which public services are being provided. Knowledge on mechanisms to report is a key ingredient not only toward resisting the tendency of government bureaucrats to use the power bestowed on them for individual gain. The fact that households' knowledge about how to report corruption can be demonstrated to be a key element in improving the delivery of public services could imply that, by providing mechanisms to better articulate their opinions and increasing civic responsibility (and ability to resist unjustified claims), measures to increase public debate and transparency can have benefits beyond the original goal of reducing the incidence of corruption. Further exploration of this link, as well as potential mechanisms that might underlie it, would be of great interest not only for Uganda but also for other countries that share similar cultural, political, and socio-economic characteristics. 
Table 1: Perceptions of bribery in different institutions, Uganda by private and public sector (percentages)

Sector of respondent

Private

\section{Low level of corruption}

Central Bank

Ministry of Foreign Affairs

Office of Ethics and Integrity

Ministry of Labor

National water and sewerage corporation

Prisons

Ministry of Finance

Ministry of Works

Ministry of Agriculture and Forestry

Administrator General's office

Ministry of Public Service

Ministry of Education

DPP

Parliament

Private companies

State House/President's Office

Medium level of corruption

IGG's office

LC 1

Sub-county Councils

NSSF

Local Administration

Ministry of Health

District councils

Privatization Unit

Immigration Department

Courts

High level of corruption

Ministry of Defense

Police excluding traffic police

Electoral commission

Tender boards

Uganda Revenue Authority

Traffic police

No. of observations

Source: Authors' own calculations based on the Institutional Module of the Uganda Second National Integrity Survey 2002.

Overall

Public

\begin{tabular}{|c|c|c|}
\hline 3.26 & 3.72 & 3.46 \\
\hline 3.77 & 4.84 & 4.24 \\
\hline 4.12 & 5.21 & 4.60 \\
\hline 5.49 & 7.64 & 6.43 \\
\hline 6.69 & 7.64 & 7.11 \\
\hline 8.58 & 8.75 & 8.65 \\
\hline 8.23 & 13.04 & 10.33 \\
\hline 8.58 & 15.08 & 11.42 \\
\hline 13.55 & 9.12 & 11.61 \\
\hline 14.07 & 11.17 & 12.80 \\
\hline 17.67 & 13.22 & 15.72 \\
\hline 19.73 & 14.9 & 17.62 \\
\hline 17.32 & 18.25 & 17.73 \\
\hline 15.78 & 23.46 & 19.14 \\
\hline 21.27 & 16.57 & 19.22 \\
\hline 21.78 & 17.69 & 19.99 \\
\hline 25.56 & 13.59 & 20.33 \\
\hline 22.3 & 18.62 & 20.69 \\
\hline 20.58 & 25.14 & 22.57 \\
\hline 30.53 & 16.95 & 24.59 \\
\hline 30.36 & 20.86 & 26.21 \\
\hline 31.22 & 25.7 & 28.81 \\
\hline 31.39 & 33.15 & 32.16 \\
\hline 39.97 & 29.42 & 35.36 \\
\hline 45.10 & 30.78 & 38.75 \\
\hline 35.47 & 43.46 & 39.02 \\
\hline 44.6 & 36.69 & 41.14 \\
\hline 58.66 & 52.51 & 55.97 \\
\hline 59.69 & 52.7 & 56.63 \\
\hline 59.52 & 55.12 & 57.60 \\
\hline 72.38 & 54.93 & 64.75 \\
\hline 73.76 & 64.99 & 69.93 \\
\hline 618 & 480 & 1098 \\
\hline
\end{tabular}


Table 2: Assessment of the prevalence of different forms of corruption according to the private and public sector

\begin{tabular}{|c|c|c|c|c|c|c|c|c|c|c|c|}
\hline & \multicolumn{2}{|c|}{ Favoritism (\%) } & \multicolumn{2}{|c|}{ Bribery $(\%)$} & \multicolumn{2}{|c|}{ Embezzlement (\%) } & \multicolumn{2}{|c|}{ Fraud $(\%)$} & \multicolumn{2}{|c|}{ Extortion (\%) } & \multirow[t]{2}{*}{ Obs. } \\
\hline & Prev. & Com. & Prev. & Com. & Prev. & Com. & Prev. & Com. & Prev. & Com. & \\
\hline Single proprietor & 67.8 & 13.8 & 53.9 & 25.7 & 54.6 & 27.0 & 26.3 & 28.3 & 17.1 & 21.7 & 152 \\
\hline Partnership & 59.8 & 20.1 & 56.7 & 22.6 & 61.0 & 20.7 & 28.7 & 31.7 & 17.7 & 26.8 & 164 \\
\hline Foreign corporation & 66.7 & 17.6 & 68.6 & 21.6 & 51.0 & 31.4 & 29.4 & 25.5 & 13.7 & 37.3 & 51 \\
\hline Local company $^{1}$ & 73.6 & 13.9 & 69.9 & 17.6 & 58.3 & 25.5 & 31.9 & 27.8 & 20.4 & 28.7 & 251 \\
\hline All private sector & 67.6 & 16.0 & 61.9 & 21.4 & 57.5 & 25.0 & 29.3 & 28.8 & 18.2 & 27.1 & 618 \\
\hline All public sector & 52.1 & 21.5 & 34.8 & 33.4 & 39.8 & 30.4 & 25.8 & 28.2 & 14.5 & 23.3 & 480 \\
\hline Total & 60.8 & 18.4 & 50.1 & 26.6 & 49.8 & 27.4 & 27.8 & 28.5 & 16.6 & 25.4 & 1098 \\
\hline
\end{tabular}

${ }^{1}$ Includes others; Pre. $=$ prevalent; Com. $=$ Common.

Source: Authors' own calculations based on the Institutional Module of the Uganda Second National Integrity Survey 2002. 
Table 3: Household characteristics

\begin{tabular}{|c|c|c|c|c|c|c|}
\hline & \multirow{2}{*}{$\begin{array}{c}\text { All } \\
\text { Uganda }\end{array}$} & \multicolumn{5}{|c|}{ Expenditure quintiles } \\
\hline & & 1 & 2 & 3 & 4 & 5 \\
\hline Female head (\%) & 14.99 & 19.57 & 13.46 & 14.70 & 13.08 & 14.12 \\
\hline Age of head (years) & 36.68 & 37.77 & 35.01 & 35.28 & 35.65 & 39.69 \\
\hline Household size & 5.70 & 4.56 & 4.95 & 5.50 & 5.99 & 7.51 \\
\hline \multicolumn{7}{|c|}{ Education of head (\%) } \\
\hline None & 9.04 & 17.28 & 8.78 & 7.52 & 6.64 & 4.93 \\
\hline Primary $1-4$ & 12.09 & 17.86 & 14.82 & 11.79 & 9.59 & 6.36 \\
\hline Primary 5-7 & 30.03 & 34.98 & 36.00 & 32.57 & 26.98 & 19.58 \\
\hline Secondary & 36.29 & 25.19 & 32.51 & 36.14 & 42.76 & 44.91 \\
\hline Tertiary & 11.78 & 3.71 & 7.39 & 11.05 & 13.57 & 23.23 \\
\hline \multicolumn{7}{|c|}{ Occupation of head (\%) } \\
\hline Farmer & 32.14 & 49.00 & 37.32 & 29.16 & 24.15 & 20.98 \\
\hline Trader & 21.15 & 14.39 & 18.10 & 21.48 & 26.04 & 25.78 \\
\hline Professional & 15.33 & 6.11 & 11.08 & 14.91 & 18.04 & 26.56 \\
\hline Craftsperson & 16.78 & 17.73 & 20.57 & 18.81 & 15.79 & 11.00 \\
\hline Student/other & 4.18 & 4.16 & 3.78 & 4.23 & 4.31 & 4.43 \\
\hline \multicolumn{7}{|c|}{ Ownership of assets (\%) } \\
\hline Bicycle/cycle/car & 49.24 & 37.49 & 45.65 & 48.42 & 54.78 & 59.93 \\
\hline Permanent house & 38.11 & 21.31 & 30.09 & 38.15 & 44.32 & 56.81 \\
\hline Rural household & 58.84 & 72.94 & 66.30 & 57.54 & 52.93 & 44.42 \\
\hline
\end{tabular}

Source: Authors' own calculations based on the Second National Integrity Survey 2002 for Uganda. 
Table 4: Knowledge of mechanisms to report corruption and actual reporting

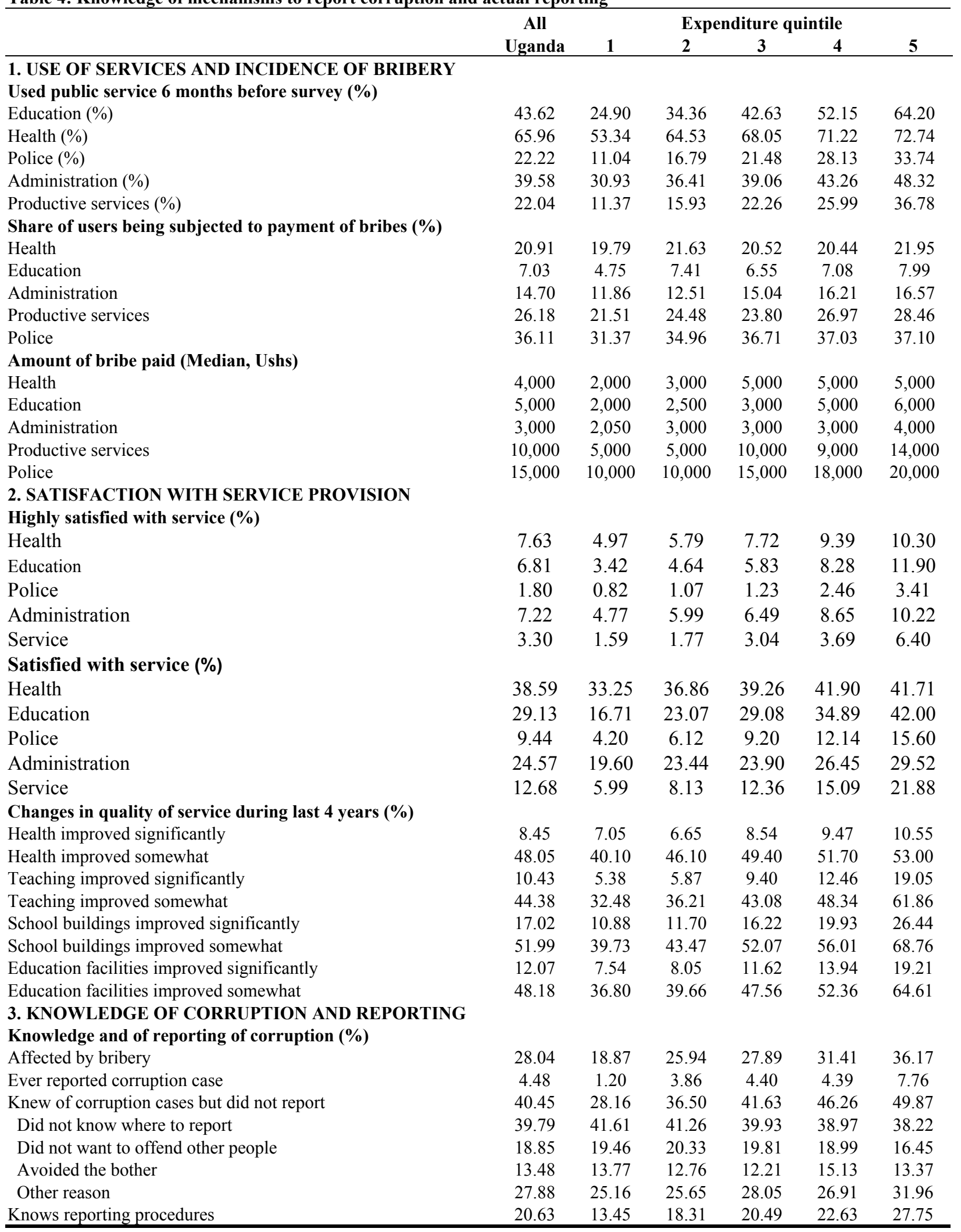

Source: Authors' own calculations based on the Second National Integrity Survey 2002 for Uganda. 
Table 5: Institutions/organizations that help in reducing corruption

\begin{tabular}{|c|c|c|c|c|c|}
\hline & All Uganda & Central & East & North & West \\
\hline \multicolumn{6}{|l|}{ High impact (\%) } \\
\hline Radio & 49.27 & 54.67 & 43.56 & 21.19 & 58.41 \\
\hline Presidents' Office/State House & 44.19 & 45.70 & 40.81 & 13.21 & 62.14 \\
\hline IGG' Office & 34.81 & 33.62 & 29.70 & 22.74 & 50.04 \\
\hline Commissions of enquiry & 34.67 & 39.69 & 25.09 & 12.78 & 45.07 \\
\hline Newspapers & 33.46 & 37.63 & 29.66 & 15.68 & 37.61 \\
\hline Church organizations & 27.59 & 29.52 & 34.59 & 22.39 & 18.77 \\
\hline Local Councils & 23.63 & 24.31 & 25.78 & 15.04 & 24.81 \\
\hline \multicolumn{6}{|l|}{ Medium impact (\%) } \\
\hline Ministry of Ethics and Integrity & 19.20 & 18.32 & 13.86 & 3.11 & 36.25 \\
\hline Television & 18.73 & 22.02 & 19.35 & 6.00 & 17.52 \\
\hline General public & 18.66 & 18.97 & 25.13 & 12.50 & 14.87 \\
\hline Members of Parliament & 16.69 & 16.95 & 17.90 & 9.39 & 19.10 \\
\hline Local politicians & 16.16 & 16.61 & 17.54 & 11.09 & 16.65 \\
\hline Human rights groups & 14.28 & 16.81 & 16.73 & 7.20 & 9.73 \\
\hline Teachers & 13.30 & 13.74 & 15.64 & 9.53 & 12.01 \\
\hline Judiciary & 13.19 & 14.05 & 12.73 & 9.75 & 13.59 \\
\hline Women's organizations & 12.70 & 12.98 & 17.01 & 5.72 & 11.68 \\
\hline Non-governmental organisations & 12.64 & 13.94 & 17.17 & 7.42 & 7.87 \\
\hline Auditor General & 11.72 & 12.54 & 11.96 & 7.49 & 11.97 \\
\hline \multicolumn{6}{|l|}{ Little impact (\%) } \\
\hline Police & 8.98 & 9.77 & 9.90 & 6.99 & 7.29 \\
\hline Universities & 8.29 & 8.75 & 10.06 & 4.45 & 7.58 \\
\hline National Bureau of Standards & 7.00 & 7.14 & 9.78 & 3.88 & 5.63 \\
\hline Professional bodies & 6.80 & 6.63 & 9.17 & 2.33 & 7.42 \\
\hline Observations & 12,200 & 5,895 & 2,475 & 1,416 & 2,414 \\
\hline
\end{tabular}

Source: Authors' own calculations based on the Second National Integrity Survey 2002 for Uganda. 
Table 6: Determinants and impact of knowledge on reporting corruption

\begin{tabular}{|c|c|c|c|c|c|c|c|}
\hline & \multirow{2}{*}{$\begin{array}{l}\text { Knowledge } \\
\text { on reporting }\end{array}$} & \multicolumn{6}{|c|}{ Household subject to corruption with respect to } \\
\hline & & Overall & Health & Education & Police & Administrative & prod. services \\
\hline $\begin{array}{l}\text { Predicted } \\
\text { knowldege }\end{array}$ & & $\begin{array}{c}-0.265^{* *} \\
(2.40)\end{array}$ & $\begin{array}{c}-0.311 * * \\
(2.53)\end{array}$ & $\begin{array}{l}0.075 \\
(0.84)\end{array}$ & $\begin{array}{c}-0.925^{* * *} \\
(3.79)\end{array}$ & $\begin{array}{c}-0.353 * * * \\
(2.58)\end{array}$ & $\begin{array}{c}-0.787 * * * \\
(3.64)\end{array}$ \\
\hline $\begin{array}{l}\text { Consumption exp. } \\
(\log )\end{array}$ & $\begin{array}{l}0.022 * * * \\
(6.72)\end{array}$ & $\begin{array}{c}0.064 * * * \\
(13.57)\end{array}$ & $\begin{array}{c}0.018 * * * \\
(3.45)\end{array}$ & $\begin{array}{l}0.006 \\
(1.53)\end{array}$ & $\begin{array}{c}0.056^{* * *} \\
(5.15)\end{array}$ & $\begin{array}{c}0.027 * * * \\
(4.54)\end{array}$ & $\begin{array}{c}0.050^{* * *} \\
(5.39)\end{array}$ \\
\hline Female head & $\begin{array}{c}-0.061 * * * \\
(5.73)\end{array}$ & $\begin{array}{c}-0.113 * * * \\
(8.31)\end{array}$ & $\begin{array}{c}-0.077 * * * \\
(5.20)\end{array}$ & $\begin{array}{l}0.002 \\
(0.17)\end{array}$ & $\begin{array}{c}-0.161 * * * \\
(4.64)\end{array}$ & $\begin{array}{c}-0.037 * * \\
(1.98)\end{array}$ & $\begin{array}{c}-0.075 * * \\
(2.37)\end{array}$ \\
\hline Permanent house & $\begin{array}{l}-0.009 \\
(1.09)\end{array}$ & $\begin{array}{l}-0.014 \\
(1.45)\end{array}$ & $\begin{array}{l}0.005 \\
(0.49)\end{array}$ & $\begin{array}{c}-0.013^{*} \\
(1.70)\end{array}$ & $\begin{array}{l}0.005 \\
(0.23)\end{array}$ & $\begin{array}{c}-0.022^{*} \\
(1.88)\end{array}$ & $\begin{array}{l}0.014 \\
(0.75)\end{array}$ \\
\hline Owns a bicycle & $\begin{array}{l}0.008 \\
(1.11)\end{array}$ & $\begin{array}{c}0.028 * * * \\
(3.20)\end{array}$ & $\begin{array}{l}0.006 \\
(0.63)\end{array}$ & $\begin{array}{l}0.004 \\
(0.59)\end{array}$ & $\begin{array}{l}-0.004 \\
(0.20)\end{array}$ & $\begin{array}{c}0.022 * * \\
(2.04)\end{array}$ & $\begin{array}{c}0.057 * * * \\
(3.28)\end{array}$ \\
\hline Business & $\begin{array}{l}-0.006 \\
(0.60)\end{array}$ & $\begin{array}{c}-0.024 * * \\
(2.02)\end{array}$ & $\begin{array}{c}-0.023^{*} \\
(1.74)\end{array}$ & $\begin{array}{c}-0.025^{* * * *} \\
(2.65)\end{array}$ & $\begin{array}{c}-0.055^{* *} \\
(2.24)\end{array}$ & $\begin{array}{l}-0.006 \\
(0.39)\end{array}$ & $\begin{array}{l}0.001 \\
(0.05)\end{array}$ \\
\hline Professional & $\begin{array}{c}0.055^{* * *} \\
(4.33)\end{array}$ & $\begin{array}{c}-0.043 * * \\
(2.50)\end{array}$ & $\begin{array}{l}-0.010 \\
(0.54)\end{array}$ & $\begin{array}{c}-0.026^{* *} \\
(2.03)\end{array}$ & $\begin{array}{l}-0.058 \\
(1.54)\end{array}$ & $\begin{array}{l}0.009 \\
(0.41)\end{array}$ & $\begin{array}{l}0.007 \\
(0.21)\end{array}$ \\
\hline Rural & $\begin{array}{c}-0.022 * * * \\
(2.68)\end{array}$ & $\begin{array}{c}0.022 * * \\
(2.30)\end{array}$ & $\begin{array}{l}0.007 \\
(0.66)\end{array}$ & $\begin{array}{l}-0.001 \\
(0.13)\end{array}$ & $\begin{array}{c}0.049 * * \\
(2.31)\end{array}$ & $\begin{array}{l}0.007 \\
(0.61)\end{array}$ & $\begin{array}{c}0.049 * * \\
(2.50)\end{array}$ \\
\hline East & $\begin{array}{c}0.036^{* * * *} \\
(3.52)\end{array}$ & $\begin{array}{l}0.114 * * * \\
(9.33)\end{array}$ & $\begin{array}{c}0.095 * * * \\
(7.19)\end{array}$ & $\begin{array}{l}0.009 \\
(0.90)\end{array}$ & $\begin{array}{c}0.120^{* * * *} \\
(4.33)\end{array}$ & $\begin{array}{c}0.043^{* * *} \\
(2.78)\end{array}$ & $\begin{array}{l}0.129 * * * \\
(5.40)\end{array}$ \\
\hline North & $\begin{array}{c}0.048^{* * * *} \\
(3.69)\end{array}$ & $\begin{array}{c}0.031^{* *} * \\
(2.07)\end{array}$ & $\begin{array}{c}0.093 * * * \\
(5.31)\end{array}$ & $\begin{array}{l}-0.021 \\
(1.62)\end{array}$ & $\begin{array}{l}-0.004 \\
(0.09)\end{array}$ & $\begin{array}{c}0.047 * * \\
(2.13)\end{array}$ & $\begin{array}{l}-0.022 \\
(0.71)\end{array}$ \\
\hline West & $\begin{array}{c}0.096^{* * * *} \\
(9.21)\end{array}$ & $\begin{array}{l}-0.007 \\
(0.44)\end{array}$ & $\begin{array}{c}-0.042^{* *} \\
(2.46)\end{array}$ & $\begin{array}{c}-0.028 * * \\
(2.33)\end{array}$ & $\begin{array}{c}0.198 * * * \\
(5.52)\end{array}$ & $\begin{array}{c}0.072 * * * \\
(3.51)\end{array}$ & $\begin{array}{l}0.032 \\
(0.92)\end{array}$ \\
\hline Lower primary & $\begin{array}{l}0.028 \\
(1.48)\end{array}$ & & & & & & \\
\hline Upper primary & $\begin{array}{c}0.054 * * * \\
(3.24)\end{array}$ & & & & & & \\
\hline Secondary & $\begin{array}{c}0.103 * * * \\
(6.14)\end{array}$ & & & & & & \\
\hline Tertiary & $\begin{array}{c}0.177^{* * *} \\
(7.90)\end{array}$ & & & & & & \\
\hline Observations & 11,888 & 11,888 & 7,855 & 5,204 & 2,664 & 4,717 & 2695 \\
\hline Log likelihood rat. & $-5,772.49$ & $-6,780.85$ & $-3,932.70$ & $-1,306.37$ & $-1,688.90$ & $-1,954.05$ & -1484.87 \\
\hline
\end{tabular}

Absolute value of z-statistics in parentheses

$*$ significant at $10 \% ; * *$ significant at $5 \%$; ** significant at $1 \%$ 
Table 7: Determinants of satisfaction with service delivery

\begin{tabular}{|c|c|c|c|c|c|}
\hline & \multicolumn{5}{|c|}{ High satisfaction with services provided by } \\
\hline & Education & Health & Police & Administration & Productive services \\
\hline \multirow{2}{*}{ Predicted knowledge } & $0.227 * * *$ & $0.083 * * *$ & $0.048 * * *$ & $0.196^{* * *}$ & $0.171 * * *$ \\
\hline & $(8.10)$ & $(2.62)$ & $(3.26)$ & $(6.33)$ & $(8.92)$ \\
\hline \multirow[t]{2}{*}{ Mean corruption in village } & $-0.073^{* * *}$ & $-0.046^{* *}$ & -0.013 & -0.011 & 0.008 \\
\hline & $(4.06)$ & $(2.40)$ & $(1.32)$ & $(0.59)$ & $(0.65)$ \\
\hline \multirow[t]{2}{*}{ Village expenditure (log) } & $0.012 * * *$ & $0.008^{*}$ & 0.002 & -0.001 & $0.006^{*}$ \\
\hline & $(2.81)$ & $(1.73)$ & $(0.85)$ & $(0.15)$ & $(1.95)$ \\
\hline \multirow[t]{2}{*}{ Rural } & 0.005 & -0.002 & -0.003 & $0.019 * * *$ & $0.007 * *$ \\
\hline & $(1.06)$ & $(0.37)$ & $(1.08)$ & $(3.47)$ & (1.99) \\
\hline \multirow[t]{2}{*}{ East Dummy } & $-0.022 * * *$ & $-0.033 * * *$ & $-0.009 * * *$ & $-0.039 * * *$ & $-0.010 * *$ \\
\hline & (3.49) & (4.99) & (2.77) & $(6.43)$ & $(2.47)$ \\
\hline \multirow{2}{*}{ North Dummy } & $-0.032 * * *$ & $-0.034 * * *$ & $-0.010 * * *$ & $-0.041 * * *$ & $-0.016^{* * *}$ \\
\hline & $(4.58)$ & (4.44) & $(2.72)$ & $(5.92)$ & $(3.51)$ \\
\hline \multirow[t]{2}{*}{ West Dummy } & $0.021 * * *$ & $0.020 * * *$ & -0.002 & $-0.023 * * *$ & $-0.008^{*}$ \\
\hline & $(3.30)$ & $(2.86)$ & $(0.71)$ & $(3.63)$ & $(1.88)$ \\
\hline Observations & 11,888 & 11,888 & 11,888 & 11,888 & 11888 \\
\hline Log likelihood ratio & $-2,845.26$ & $-3,161.29$ & $-1,047.38$ & $-3,045.92$ & -1672.77 \\
\hline
\end{tabular}

Absolute value of $\mathrm{z}$-statistics in parentheses

* significant at 10\%; ** significant at 5\%; *** significant at $1 \%$ 
Table 8: Impact of knowledge and corruption on changes in quality of service delivery

\begin{tabular}{lcccc}
\hline & \multicolumn{3}{c}{ Significant improvement in .. } \\
& Teaching & Buildings & Facilities & Health \\
\hline Predicted knowledge on reporting & $0.357^{* * *}$ & $0.278^{* * *}$ & $0.286^{* * *}$ & $0.157^{* * *}$ \\
& $(6.68)$ & $(4.13)$ & $(4.88)$ & $(3.54)$ \\
Mean overall corruption in village & $-0.103^{* * *}$ & 0.023 & 0.007 & -0.028 \\
& $(3.12)$ & $(0.61)$ & $(0.20)$ & $(1.10)$ \\
Village-level expenditure (log) & $0.043^{* * *}$ & $0.047 * * *$ & $0.033^{* * *}$ & 0.006 \\
& $(5.52)$ & $(4.86)$ & $(3.92)$ & $(0.87)$ \\
Rural & $-0.028^{* * *}$ & -0.004 & -0.003 & $0.018^{* *}$ \\
& $(2.89)$ & $(0.37)$ & $(0.26)$ & $(2.32)$ \\
East & $-0.056^{* * *}$ & $0.026^{*}$ & -0.016 & $-0.015^{*}$ \\
& $(5.10)$ & $(1.88)$ & $(1.34)$ & $(1.74)$ \\
North & $-0.106^{* * *}$ & $-0.098^{* * *}$ & $-0.117 * * *$ & $-0.057^{* * *}$ \\
& $(8.43)$ & $(6.05)$ & $(8.46)$ & $(5.54)$ \\
West & -0.004 & $-0.033^{* *}$ & -0.018 & -0.015 \\
& $(0.36)$ & $(2.20)$ & $(1.37)$ & $(1.58)$ \\
\hline Observations & 7,620 & 7,620 & 7,620 & 9,018 \\
Log likelihood ratio & $-3,238.22$ & $-4,350.84$ & $-3,614.35$ & $-3,132.85$ \\
\hline Absolut valu
\end{tabular}

Absolute value of $z$-statistics in parentheses

* significant at 10\%; ** significant at 5\%; *** significant at $1 \%$ 


\section{References:}

Acemoglu, D. 2003. "Institutional Causes, Macroeconomic Symptoms: Volatility, Crises and Growth." Journal of Monetary Economics 50 (1): 49-123.

Ades, A. and R. Di Tella. 1997. "National Champions and Corruption: Some Unpleasant Interventionist Arithmetic." Economic Journal 107 (443): 1023-42.

Alesina, A. and B. Weder. 2002. "Do Corrupt Governments Receive Less Foreign Aid?" American Economic Review 92 (4): 1126-37.

Angrist, J. D. 1991. "Instrumental Variables Estimation of Average Treatment Effects in Econometrics and Epidemiology." National Bureau of Economic Research Technical Paper: 115.

Bardhan, P. 1997. "Corruption and Development: A Review of Issues." Journal of Economic Literature 35 (3): $1320-46$.

Bardhan, P. K. 2000. "Understanding Underdevelopment: Challenges for Institutional Economics from the Point of View of Poor Countries." Journal of Institutional and Theoretical Economics 156 (1): 216-35.

Batra, G., D. Kaufmann and A. H. W. Stone. 2003. Investment climate around the world: Voices of the firms from the World Business Environment Survey Directions in Development series. Washington, D.C.: World Bank.

Bengoa, M. and B. Sanchez-Robles. 2003. "Foreign Direct Investment, Economic Freedom and Growth: New Evidence from Latin America." European Journal of Political Economy 19 (3): 529-45.

Besley, T. and R. Burgess. 2002. "The Political Economy of Government Responsiveness: Theory and Evidence from India." Quarterly Journal of Economics 117 (4): 1415-51.

Broadman, H. G. and F. Recanatini. 2002. "Corruption and Policy: Back to the Roots." Journal of Policy Reform 5 (1): $37-49$.

Burnside, C. and D. Dollar. 2000. "Aid, Policies, and Growth." American Economic Review 90 (4): 847-68.

Djankov, S. 2002. "The Regulation of Entry." Quarterly Journal of Economics 117 (1): 1-37.

Ebrahim, A. 2003. "Accountability in Practice: Mechanisms for NGOs." World Development 31 (5): 813-29.

Eigen, P. 2002. "Measuring and Combating Corruption." Journal of Policy Reform 5 (4): 187-201.

Ellis, F. and G. Bahiigwa. 2003. "Livelihoods and Rural Poverty Reduction in Uganda." World Development 31 (6): $997-1013$.

Esfahani, H. S. and M. T. Ramirez. 2003. "Institutions, Infrastructure, and Economic Growth." Journal of Development Economics 70 (2): 443-77.

Feld, L. P. and S. Voigt. 2003. "Economic Growth and Judicial Independence: Cross-Country Evidence Using a New Set of Indicators." European Journal of Political Economy 19 (3): 497-527.

Fisman, R. and R. Gatti. 2002a. "Decentralization and Corruption: Evidence across Countries." Journal of Public Economics 83 (3): $325-45$.

Fisman, R. and R. Gatti. 2002b. "Decentralization and Corruption: Evidence from U.S. Federal Transfer Programs." Public Choice 113 (1-2): 25-35.

Francis, P. and R. James. 2003. "Balancing Rural Poverty Reduction and Citizen Participation: The Contradictions of Uganda's Decentralization Program." World Development 31 (2): 325-37.

Friedman, E. J., S. Johnson, D. Kaufmann and P. Zoido-Lobaton. 2000. "Dodging the grabbing hand: The determinants of unofficial activity in 69 countries." Journal of Public Economics 76 (2): 459-93.

Goetz, A. M. and R. Jenkins. 2002. "Voice, Accountability and Human Development: The Emergence of a New Agenda." Background Paper for the 2002 Human Development Report. Geneva and New York: UNDP.

Goldsmith, A. A. 2003. "Perceptions of Governance in Africa: A Survey of Business and Government Leaders." Journal of African Business 4 (3): 25-53.

Gomez, K. and S. Gallon. 2002. "El impacto de la corrupcion sobre el crecimiento economico colombiano, 1990-1999." Lecturas de Economia 0 (57): 49-85.

Greene, W. H. 1995. Identification problems in the social sciences (book review)

Harms, P. and H. W. Ursprung. 2002. "Do Civil and Political Repression Really Boost Foreign Direct Investments?" Economic Inquiry 40 (4): 651-63.

Knack, S. 2001. "Aid Dependence and the Quality of Governance: Cross-Country Empirical Tests." Southern Economic Journal 68 (2): 310-29.

Mauro, P. 1995. "Corruption and Growth." Quarterly Journal of Economics 110 (3): 681-712. 
Mauro, P. 1998. "Corruption and the Composition of Government Expenditure." Journal of Public Economics 69 (2): $263-79$.

May, J. W., W. Pyle and P. M. Sommers. 2002. "Does Governance Explain Unofficial Activity?" Applied Economics Letters 9 (8): 537-9.

Merhotra, S. 2002. "Basic Social Services for All? Ensuring Accountability through Deep Democratic Decentralization." Background Paper for the 2002 Human Development Report. Geneva and New York: UNDP.

Mo, P. H. 2001. "Corruption and Economic Growth." Journal of Comparative Economics 29 (1): 66-79.

Nugent, J. B. and J. A. Robinson. 2002. "Are Endowments Fate?" CEPR Working Paper 3206. London.

Reinikka, R. and J. Svensson. 2002. "Coping with Poor Public Capital." Journal of Development Economics 69 (1): 51-69.

Republic of Uganda. 2002a. "Leadership Code Act, 2002." Acts Supplement No. 8, Uganda Printing and Publishing Company, Entebbe.

Republic of Uganda. 2002b. "Second National Integrity Survey: Final Report." Kampala: Inspectorate of Government.

Rivera-Batiz, F. L. 2002. "Democracy, Governance, and Economic Growth: Theory and Evidence." Review of Development Economics 6 (2): 225-47.

Smarzynska, B. and S. J. Wei. 2001. "Corruption and Foreign Direct Investment: Firm-Level Evidence." CEPR Discussion Paper: 2967.

Stromberg, D. 2001. "Mass Media and Public Policy." European Economic Review 45 (4-6): 652-63.

Svensson, J. 2003. "Who Must Pay Bribes and How Much? Evidence from a Cross Section of Firms." Quarterly Journal of Economics 118 (1): 207-30.

Tanzi, V. 1998. "Corruption around the World: Causes, Consequences, Scope and Cures." IMF Staff Papers 45 (4): $559-94$.

Tanzi, V. and H. Davoodi 2000. "Corruption, Public Investment and Growth." Cheltenham UK, Edward Elgar

Van Rijckeghem, C. and B. Weder. 2001. "Bureaucratic Corruption and the Rate of Temptation: Do Wages in the Civil Service Affect Corruption, and by How Much?" Journal of Development Economics 65 (2): 307-31. 